$0.56 * \mathrm{SQRT}(\mathrm{TJC})+0.28 * \mathrm{SQRT}(\mathrm{SJC})+0.7 \ln \quad$ (ESR) + $0.014 \%$ (pt global (VAS)).

DAS responses were characterised as ?None?, ?Moderate? or ?Good? using DAS scores at 102 week and change in DAS from baseline to 102 week. Patients with ?Good? or ?Moderate? response were considered DAS responders. Fisher?s exact test was used to compare proportion of patients with DAS response by treatment group.

Results Clinical responses as measured by ACR20 and DAS correlated with each other; however, overall the response rate was higher with the DAS. At week 102, 84\% of patients achieving ACR20 response were also responders using DAS; $45 \%$ of ACR20 non-responders were DAS responders. The DAS showed a statistically significant difference for each infliximab treatment group vs placebo $(\mathrm{p}<0.001)$. ACR20 and DAS response rate at Wk 102 are presented below, by treatment group.

\begin{tabular}{|c|c|c|c|c|c|c|}
\hline & MTX Alone & $\begin{array}{l}3 \mathrm{mg} / \mathrm{kg} \\
\mathrm{q} 8 \mathrm{wks}\end{array}$ & $\begin{array}{l}3 \mathrm{mg} / \mathrm{kg} \\
\mathrm{q} 4 \mathrm{wks}\end{array}$ & $\begin{array}{l}10 \mathrm{mg} / \mathrm{kg} \\
\mathrm{q} 8 \mathrm{wks}\end{array}$ & $\begin{array}{l}10 \mathrm{mg} / \mathrm{kg} \\
\mathrm{q} 4 \mathrm{wks}\end{array}$ & $\begin{array}{l}\text { Total } \\
\text { Infliximab }\end{array}$ \\
\hline N & 88 & 86 & 86 & 87 & 81 & 340 \\
\hline ACR20 & $16 \%$ & $42 \%$ & $40 \%$ & $48 \%$ & $40 \%$ & $42 \%$ \\
\hline DAS & $21 \%$ & $54 \%$ & $54 \%$ & $68 \%$ & $53 \%$ & $57 \%$ \\
\hline
\end{tabular}

Conclusion Responses assessed with ACR20 and DAS have previously been shown to correlate. Analysis of data from the ATTRACT trial suggests that the DAS may be more sensitive to clinical improvement. The improved sensitivity of DAS, and the fact that it evaluates both change in response to therapy and also extent of residual disease activity, support its routine use as an endpoint in clinical trials.

\section{FRI0072 METHOTREXATE IN RHEUMATOID ARTHRITIS: A 5 YEAR PROSPECTIVE STUDY}

AM Stankovic, BK Lovic, JM Nedovic, AN Dimic, SK Stojanovic, BN Stamenkovic, VR Skakic. Rheumatology, Institute of Rheumatology and Cardiology, Nis, Yugoslavia

10.1136/annrheumdis-2001.1201

\section{Background}

Objectives The aim was to evaluate the efficacy and tolerability of low dose of longterm Methotrexate (MTX) treatment of rheumatoid arthritis (RA).

Methods This study examines prospectively the response to oral MTX (5 ? $12,5 \mathrm{mg}$ ) over a 5 year period of 70 patients (pts) with active RA. 54 pts were female, mean age 53,61 $\pm 12,8$ years range (27 ? 76) and mean diseases duration 9,76 \pm 7,58 years (range 0,6 ? 35). Patients who were receiving Prednizone at entry to the trial, were maintained by the same dose, not exceeding $10 \mathrm{mg} /$ day. Clinical evaluation were performed by the same physician ? investigator every 3 months for the first year of the study and every 6 months thereafter. Every 4 weeks complete blood cound and every 12 weeks thereafter complete erytrocyte sedimentation (ERS), blood count, serum creatinine and liver blood tests were obtained. Patients were assessed at 0 stage (beginning) with 70 pts, after 3 months (mts) (with 62), $6 \mathrm{mts}$ (with 52), $12 \mathrm{mts}$ (with 49), $24 \mathrm{mts}$ (with 36), $36 \mathrm{mts}$ (with 26), $48 \mathrm{mts}$ (with 13), and after $60 \mathrm{mts}$ (with 11) patients.

Results $11(15,7 \%)$ pts completed the 5 year study, $14(20 \%)$ dropped out because of an adverse event or due to inefficacy.
After 3, 6, 12, 24, $36 \mathrm{mts}$ of treatment a good clinical response was shown by signiffcant clinical improvement in the joint swelling ( $\mathrm{p}<0,001)$, morning siffness $(\mathrm{p}<0,001)$, as well as in both physicians and patients assessment of the disease activity ( $\mathrm{p}$ $<0,001)$ compared to pretreatment values. The clinical improvement was also associated with a decrease of ESR after 3, 6, $12 \mathrm{mts}$ ( $\mathrm{p}<0,001)$, after 24 and $36 \mathrm{mts}(\mathrm{p}<0,05)$. Although a sustained clinical response was noted in the diseases variables during the 5 year study, there was no significant difference noted in the improvement in the joint swelling after 48 and $60 \mathrm{mts}$, in duration of morning stiffness and in decrease of ESR after $60 \mathrm{mts}$ of treatment.

Conclusion Methotrexate therapy appears to be effective and safe in the treatment of RA in this 5 year prospective study

\section{REFERENCE}

1 Weinblatt ME, Maier AL, Fraser PA, Coblyn S. Longterm prospective study of methotrexate in rheumatoid arthritis. Conclusion after 132 months of therapy. J Rheum. 1998;25(2):239-42

\section{FRI0073 TOPICAL NERVE GROWTH FACTOR FOR THE TREATMENT OF CHRONIC LEG ULCERS IN RHEUMATOID ARTHRITIS}

${ }^{1} \mathrm{~S}$ Generini, ${ }^{2} \mathrm{M}$ Tuveri, ${ }^{2} \mathrm{~L}$ Aloe, ${ }^{1} \mathrm{M}$ Matucci Cerinic. ${ }^{1}$ Department of Internal Medicine, Section of Rheumatology, Florence, Italy; ${ }^{2} \mathrm{CNR}$, Institute of Neurobiology, Rome, Italy

\subsection{6/annrheumdis-2001.1202}

Background Connective tissue diseases and, in particular, rheumatoid arthritis (RA), may provoke a cutaneous vasculitis leading to skin ulceration very difficult to heal. A depletion of neuropeptides from the nerve endings may contribute to the retardation of wound contraction and healing. ${ }^{1}$ Nerve Growth Factor (NGF) is a neurotrophic and immunomodulatory factor that, in the skin, contributes to the control of cutaneous morphogenesis, wound healing and inflammation. ${ }^{2}$

Objectives Evaluate the efficacy of topical NGF administration in the treatment of vasculitic ulcers in course of RA and systemic sclerosis (SSc).

Methods Four long lasting RA patients $(3 \mathrm{~F}, 1 \mathrm{M}$, age $73 \pm 8.7$; disease duration $17 \pm 6.2 \mathrm{yrs})$ and $4 \mathrm{SSc}$ patients $(4 \mathrm{~F}$, age $58.25 \pm 5.5$; disease duration $12 \pm 4.3$ ), were selected. All patients presented vasculitic chronic leg ulcers showing very poor or absent response to systemic and local treatments. Ulcers were treated daily with $50 \mu \mathrm{g}$ of NGF $(0.01 \%$ dissolved in saline solution) for 4 weeks and twice a week in the following month. Before the application of NGF, fibrin or scab were mechanically removed. Eventually the lesion was dressed with a hydrocolloid patch (Duoderm, Convatec, England). Size and characteristics of the ulcers were recorded twice a week.

Results During the first 2 weeks of treatment, the 4 patients with RA showed a rapid improvement of leg ulcers (both in size and descriptive parameters such as pain, presence of granulation, absence of inflammation), followed by a slower but progressive reduction of size which lead, in all cases, to healing within $5 / 8$ weeks. In SSc patients, the ulcers showed an amelioration in size and characteristics during the first 2 weeks but, in the following weeks, the healing stopped and went back to the torpid course that characterised the ulcers before the treatment. None of them achieved the healing after 8 weeks.

Conclusion In RA patients treated with NGF, despiteb the chronicity of the disease and of the ulcers, a rapid healing was achieved. In these cases, NGF was able to restore the progressive 
cascade of events leading to wound healing, perhaps through its promoting activity on keratinocytes proliferation and vascular neoangiogenesis. ${ }^{4}$ Topical application of NGF may represent a powerful pharmacological tool that may reduce and/or overcome the development of vasculitic ulcers.

\section{REFERENCES}

1 Engin C, Demirkan F, Ayhan S, Atabay K, Baran NK. Delayed effect of denervation on wound contraction in rat skin. Plast Reconstr Surg. 1996;98:1063-7

2 Di Marco E, Marchisio PC, Bondanza S, et al. Growth regulated sysnthesis and secretion of biologically active Nerve Growth Factor by human keratinocytes. I Biol Chem. 1991;266:21718-22

3 Bocchini G, Angeletti PU. The NErve Growth Factor: purification as a 30.000molecular weight protein. Proc Natl Acad Sci USA 1980;6:451-64

4 Wilkinson DI, Theeuwes MJ, Farber EM. Nerve Growth Factor increases the mitogenicity of certain growth factors for cultured human keratinocytes: a comparison with epidermal growth factor. Exp Dermatol. 1994;3:239-45

\section{FRI0074 ADENOVIRAL-BASED OVEREXPRESSION OF TIMP-1 REDUCES TISSUE DAMAGE IN THE JOINTS OF TNF-A- TRANSGENIC MICE}

G Schett, S Hayer, M Tohidast-Akrad, Q Xu, G Kollias, G Steiner, J Smolen. Department of Rheumatology, University of Vienna, Vienna, Austria

\subsection{6/annrheumdis-2001.1203}

Background Rheumatoid arthritis is a prototype of a destructive inflammatory disease. Inflammation triggered by the overexpression of TNF-a is a driving force of this disorder and mediates tissue destruction. The particular impact of TNF-a-induced molecules, such as matrix metalloproteinases, in tissue destruction is however unknown.

Objectives Herein, the effect of an overexpression of tissue inhibitor of metalloproteinases (TIMP)-1, a physiological antagonist of metalloproteinases, was studied in the arthritis model of TNF- a-transgenic mice.

Methods Systemic treatment was carried out by replicationdefective adenoviral vectors for TIMP-1 (AdvTIMP1, $\mathrm{n}=7$ ) or b-galactosidase (AdvLacZ, $n=6$ ) or phosphate buffered saline (PBS, $\mathrm{n}=7$ ), which were applied once at the onset of arthritis. Clinical, serological, radiological and histological outcomes were assessed 18 days after the treatment.

Results The AdvTIMP1 group showed a significantly reduced paw swelling and increased grip strength compared to the two control groups, whereas total body weight, TNF-a and IL-6 levels were similar in all three groups. Radiological assessment revealed a significant reduction of joint destruction in the AdvTIMP1 group; this was confirmed by histological analyses, showing reduced formation of pannus as well as erosions in the AdvTIMP1 group as compared to the AdvLacZ- and PBS- control groups. The formation of arthritis-specific autoantibodies to hnRNP-A2 was not observed in the AdvTIMP1 group but was present in the two control groups.

Conclusion These results indicates a central role of matrix metalloproteinases in TNF-a-mediated tissue damage in vivo and a promising therapeutic role of TIMP-1.

\section{FRI0075 COMP LEVELS IN SERUM LOWERED AFTER SIX MONTHS TREATMENT WITH ETANERCEPT IN PATIENTS WITH RHEUMATOID ARTHRITIS}

${ }^{1} \AA$ Thörner, ${ }^{2} \mathrm{C}$ Freiburghaus, ${ }^{1} \mathrm{~S}$ Ernestam, ${ }^{1} \mathrm{~J}$ Bratt. 'Department of Rheumatology, Huddinge University Hospital, Stockholm; ${ }^{2}$ AnaMar, Med., Lund, Sweden

10.1136/annrheumdis-2001.1204

\section{Background}

Objectives The aim of this study was to evaluate Cartilage Oligometric Matrix Protein (COMP) levels during TNFalfa-blocking therapy with Etanercept (Enbrel) in patients with rheumatoid arthritis (RA). Previous studies have suggested that serum COMP levels is a marker for joint destruction in RA.

Methods 38 patients (34 female, 4 male) with active, longstanding RA were treated with Etanercept $25 \mathrm{mg}$ x2/week. The efficacy measures included ACR response rates after treatment for 3 and 6 months. COMP was measured in serum using sandwich ELISA from AnaMar Med. Lund. Wilcoxon Matched Paired Test was used for statistical analysis.

Results ACR 20, 50 and 70 responses were demonstrated for $79 \%, 29 \%$ and $5 \%$ of the patients, respectively, at 3 months and $68 \%, 35 \%$ and $11 \%$ at 6 months. $21 \%$ of the patients were still non-responders to Etanercept at 3 months and 32\% after 6 months. The ACR response rates at 12 months will be presented at the meeting. A significant decrease $(p<0,05)$ in serum COMP levels was seen after 6 and 12 months treatment with Etanercept but not after 3 months. At 3 months COMP levels showed a high degree of variability.

Conclusion Significant reduction in serum COMP levels were seen after six months TNFalfa-blocking therapy and was maintained after 12 months. The COMP levels at 3 months gave no indication regarding outcome of treatment.

\section{FRI0076 REDUCED TOXICITY OF METHOTREXATE IN RHEUMATOID}

MN Kotevska, M Grlickov, A Pusevski, J Calovski, S Percinkova, N Marina, D Antova, M Trajanoska, E Grlickova. Clinic of Rheumatology, Clinical Centre Skopje, Medical Faculty, Skopje, Macedonia

\subsection{6/annrheumdis-2001.1205}

\section{Background}

Objectives The aim of the study was to investigate whether folic acid (FA) supplementation in patients with rheumatoid arthritis reduces methotrexate (MTX) toxicity.

Methods It was a prospective randomised study. Total of 53 patients with RA who had never used methotrexate before, were randomly assigned to receive either MTX alone (group 1) or MTX and $5 \mathrm{mg}$. folic acid (group 2). Patients were evaluated for treatment toxicity at three monthly intervals for two years.

Results 1. Significant increases in the hepatic transaminases, ALT and AST, occurred in group 1, over the trial period. 2. After 6 months an increased incidence of nausea in group 1 , occurred (43\% vs. $7 \%$ ). 3. More patients withdrew from the study early because of side-effects in group 1 (39\% vs. $18 \% \mathrm{p}=0,025)$.

Conclusion Our results indicate that it is inportant to continue FA supplementation long term to avoid patients discontinuing MTX treatment due to side-effects. They aslo suggest that FA supplementation can prevent the changes in AST and ALT. 